\title{
PERANCANGAN DASHBOARD UNTUK MONITORING PENERIMAAN MAHASISWA BARU
}

\author{
Margaretha Yohanna ${ }^{1)}$, Yolanda Y. P Rumapea ${ }^{2)}$ \\ ${ }^{1}$ Program Studi Teknik Informatika, Universitas Methodist Indonesia \\ ${ }^{2}$ Program Studi Sistem Informasi, Universitas Methodist Indonesia \\ Email: yohanna.na2@gmail.com ${ }^{1)}$
}

\begin{abstract}
ABSTRAK
Salah satu tujuan perguruan tinggi adalah menghasilkan generasi muda yang berkualitas. Untuk mendukung hal tersebut, diperlukan suatu sistem yang baik, salah satunya sistem informasi penerimaan mahasiswa baru. Di salah satu universitas swasta di kota Medan sistem informasi penerimaan mahasiswa baru yang digunakan masih bersifat konvensional, dimana pencatatan data-data mahasiswa baru masih berupa teks dan angka. Dengan sistem dashboard yang dikembangkan, memudahkan pihak rektorat dan dekanat dalam mengatur strategi untuk mencapai target yang diinginkan dalam penerimaan mahasiswa baru. Selain itu melalui bantuan dashboard, tampilan yang dihasilkan menarik dan informasi yang disajikan mudah dipahami sehingga pihak Rektorat dan Dekanat dapat dengan mudah memantau jumlah mahasiswa baru. Dalam penelitian ini, data yang digunakan yaitu data mahasiswa baru di kampus 1 salah satu perguruan tinggi swasta di kota Medan. Hasil penelitian ini diperoleh suatu sistem dashboard yang memudahkan pihak rektorat dan dekanat dalam mengatur strategi penerimaan mahasiswa baru agar tidak terjadi penurunan jumlah mahasiswa.
\end{abstract}

\section{Kata kunci: dashboard, grafik, mahasiswa baru.}

\begin{abstract}
One of the goals of private universities is to assist the Government in the field of education and produce a quality young generation. To support this, a good system is required, one of which is a new admissions information system. In one of the private universities in the city of Medan the new admissions information system used is still conventional, where the recording of new student data is still text and numbers. With the dashboard system developed, facilitate the Rectorate and Deanery in regulating the strategy to reach the desired target in the admission of new students. In addition through the help of the dashboard, the resulting display is interesting in the form of relevant graphs so that Rectorate and Deanery can easily monitor all aspects of the admission performance of new students. In this research, data used is the data of new students of the private colleges in the city of Medan. The results of this research obtained a dashboard system that facilitates the Rectorate and Deanery in regulating the acceptance strategies of new students to avoid a decline in student numbers.
\end{abstract}

Keywords: dahsboard, graphs, new students.

\section{PENDAHULUAN}

Persaingan di dunia Pendidikan sekarang semakin kompetitif, terutama bagi perguruan tinggi swasta. Para mahasiswa yang tidak diterima di perguruan tinggi negeri akan mencari universitas swasta terbaik untuk melanjutkan pendidikannya. Salah satu tujuan perguruan tinggi swasta adalah menghasilkan generasi muda yang berkualitas. Untuk mendukung Pendidikan yang berkualitas khususnya dalam bidang teknologi informasi, diperlukan suatu sistem pengolahan penerimaan mahasiswa baru [1] Teknologi informasi mampu meningkatkan efektifitas, efisiensi, daya saing dan mendukung kegiatan manajerial organisasi (termasuk institusi Pendidikan).

Salah satu penggunaan teknologi informasi di salah satu universitas swasta di Medan yaitu sistem informasi penerimaan mahasiswa baru, di mana sistem tersebut digunakan untuk mencatat data-data mahasiswa baru. Sistem informasi yang digunakan masih bersifat konvensional, pencatatan data-data mahasiswa baru masih berupa teks dan angka. Pelaporan yang dihasilkan juga belum memenuhi sebagai alat penunjang dalam mendukung keputusan karena masih berupa data dan belum berupa suatu model informasi. Sistem pelaporan yang kurang baik dan kurang menarik dapat menghambat dalam proses monitoring pencapaian tujuan yang diinginkan sehingga keputusan yang diambil tidak bisa dilakukan dengan cepat untuk meningkatkan kinerja bagian penerimaan mahasiswa baru.

Untuk menunjang dalam penyediaan informasi yang menarik, data-data yang ada dapat direpresentasikan menggunakan dashboard system. Dashboard merupakan alat untuk menyajikan 
informasi secara sekilas yang memberikan tampilan antarmuka dalam berbagai bentuk, seperti diagram, laporan, indicator visual, mekanisme alert, yang dipadukan dengan sistem informasi yang dinamis dan relevan [2]. Informasi yang disajikan mudah dipahami dan memberikan gambaran mengenai informasi yang ditampilkan. Dashboard secara umum memiliki tampilan yang sesuai dan mudah dimengerti oleh pihak rektorat dan dekanat.

Penelitian dimulai dengan pengumpulan data mahasiswa baru, seperti data calon mahasiswa, tingkat kelulusan ujian masuk, data bagi mahasiswa yang melakukan registrasi ulang, data asal sekolah, data orangtua dan data pendukung lainnya. Tingkat pencapaian kinerja diukur dari KPI (Key performance Indikator) yang disusun oleh bagian penerimaan mahasiswa baru sehingga bisa diperoleh perbandingan pencapaian kinerja. Key Performance Indicator (KPI) merupakan representasi dari sejumlah langkah - langkah pengukuran yang berfokus pada aspek - aspek organisasi kinerja yang paling penting untuk kesuksesan saat ini dan masa depan dari organisasi [3]. Dengan sistem dashboard yang dikembangkan, pihak rektorat dan dekanat dapat dengan mudah memantau semua aspek kinerja penerimaan mahasiswa baru serta dapat dengan cepat mengatur strategi penerimaan mahasiswa baru agar jumlah mahasiswa dapat terus meningkat.

\subsection{Dashboard}

Dashboard merupakan salah satu penyelesaian dalam penyajian dan visualisasi data, dengan menggunakan sistem dashboard, data dan informasi strategis dapat ditampilkan secara online, cepat, dan mudah dipahami oleh pemimpin organisasi [5]. Dashboard merupakan turunan dari sistem informasi eksekutif atau Executive Information System (EIS) dan Decision Support Systems (DSS) dengan sistem data yang lebih kuat dan memanfaatkan Key Performance Indicators (KPI).

Tujuan penggunaan dashboard menurut Eckerson yaitu:

1. Mengkomunikasikan Tujuan dan Strategi

Mengkomunikasikan tujuan dan strategi yang dibuat oleh bagian eksekutif kepada semua pihak yang mempunyai kepentingan, sesuai dengan tingkat dan perannya dalam organisasi tersebut.

2. Memonitor dan Menyesuaikan Pelaksanan Strategi

Memonitoring pelaksanan dari rencana dan strategis yang telah disusun pihak eksekutif untuk mengidentifikasi masalah secara kritis dan membuat strategi untuk mengatasi masalah tersebut.

3. Menyampaikan Wawasan dan Informasi ke Semua Pihak

Menyampaikan informasi kepada semua pihak dengan menggunakan grafik, simbol, bagan dan warna yang memudahkan pengguna dalam memahami informasi secara benar sehingga dapat meningkatkan wawasan pembaca atau pengguna dalam melihat informasi tersebut [6].

Menurut Aanderud dan Homes, beberapa tahapan yang harus dilakukan dalam membangun sebuah dashboard, yaitu:

1. Tentukan hal apa yang ingin diukur oleh pengguna.

2. Membuat layout dan membangun sebuah protype yang mengacu kepada desain akhir.

3. Mengumpulkan data-data pendukung.

4. Membuat final design dari dashboard.

5. Perhatikan interaksi penggunar dengan dashboard untuk memastikan penerapannya [7].

Beberapa prinsip yang harus diperhatikan dalam membuat dashboard, yakni:

1. Menyediakan informasi berupa Key Performance Indicator (KPI) yang spesifik.

2. Mengintegrasikan beberapa informasi dalam single screen.

3. Bersifat interaktif dan informasi yang saling terintegrasi.

4. Dapat melakukan beberapa hal sekaligus, diantaranya: analisis, monitoring, dan prediksi.

5. Bersifat personal, yaitu bergantung kepada kebutuhan pengguna.

6. Memungkinkan kolaborasi dan komunikasi antar section [8].

Terdapat tiga jenis dashboard, yaitu:

1. Tactical Dashboard

Tactical dashboard bertujuan untuk mengukur produktivitas dan efektivitas dalam jangka pendek. Jenis dashboard ini sering digunakan oleh contributor individu.

2. Operational Dashboard

Operational dashboard bertujuan untuk mengukur fungsi bisnis yang spesifik, padat, atau tingkat unit bisnis dalam jangka pendek. Jenis dashboard ini dapat dikembangkan secara potensial untuk knowledge worker atau local team manager.

3. Strategic Dashboard

Strategic dashboard dibangun untuk tingkatan pengaturan kebijakan dari subuah instansi atau organisasi. Jenis dashboard ini bertujuan untuk menampilkan metrik yang menggambarkan strategi dan tujuan organisasi [9].

Beberapa karakteristik dari dashboard yaitu

[10]

1. Synergetic.

2. Monitor.

3. Accurate.

4. Responsive.

5. Timely.

6. Interactive.

7. More data history.

8. Personalized. 


\subsection{Key Performance Indicator (KPI)}

Key Performance Indicator (KPI) adalah metrik finansial maupun nonfinansial yang digunakan untuk membantu organisasi dalam menentukan dan mengukur kemajuan terhadap sasaran organisasi [1]. Key Performance Indicator (KPI) merupakan representasi dari sejumlah langkah-langkah pengukuran yang berfokus pada aspek-aspek organisasi kinerja yang paling penting untuk kesuksesan saat ini dan masa depan dari suatu organisasi. KPI umumnya berkaitan dengan strategi organisasi yang diterapkan oleh Teknik, seperti kartu scor berimbang BSC (Balanced Score Card). Kunci utama dalam mengidentifikasi KPI yaitu:

1. Memiliki proses bisnis yang telah ditetapkan sebelumnya.

2. Memiliki tujuan yang jelas dan persyaratan kinerja untuk seluruh proses bisnis.

3. Memiliki pengukuran kuantitatif dan kualitatif dari hasil kerja dengan saran yang ditetapkan.

4. Meneliti penyimpangan dan titik lemah proses untuk mencapai sasaran jangka pendek.

\section{METODE PENELITIAN}

\subsection{Tahapan Umum Penelitian}

Beberapa tahapan yang dilakukan dalam merancang dashboard untuk monitoring penerimaan mahasiswa baru yang dapat dilihat pada Gambar 1 .

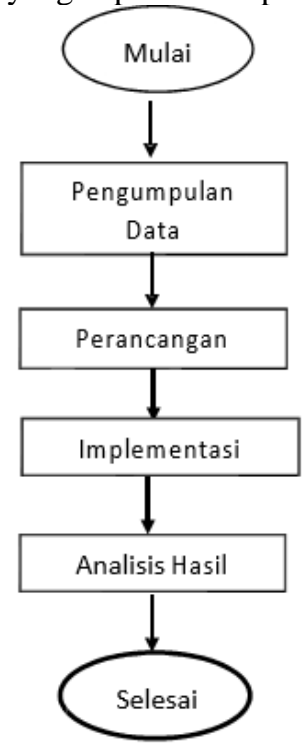

Gambar 1 Tahapan Umum Penelitian

\subsection{DFD Level 0 / Diagram Konteks}

DFD level 0 / Diagram konteks dirancang untuk menjelaskan hubungan antara sistem dengan dunia luarnya. Perancangan dimulai secara global hingga ke model yang paling detail. DFD level 0 dapat dilihat pada Gambar 2.

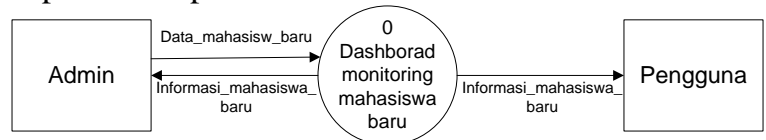

Gambar 2 DFD Level 0

\subsection{Entity Relational Diagram / ERD}

Gambar 3 merupakan ERD dari perancangan dashboard dalam monitoring penerimaan mahasiswa baru.

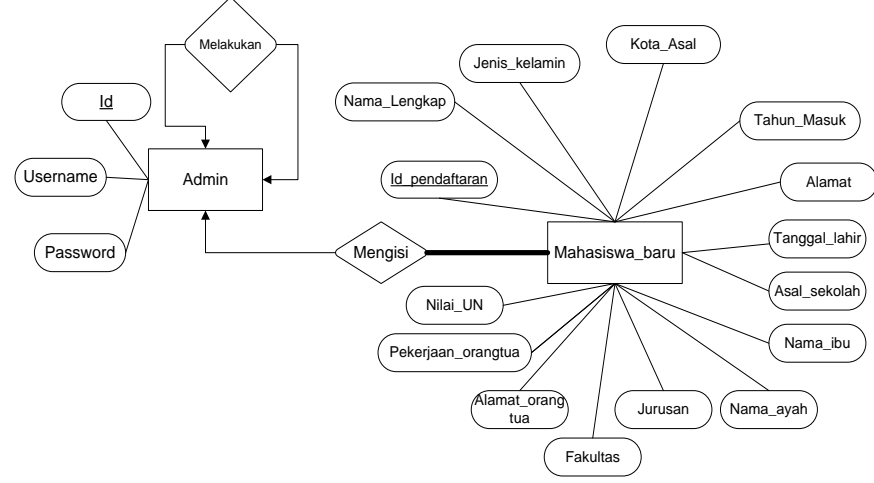

Gambar 3 ERD

\section{HASIL DAN PEMBAHASAN}

\subsection{Tampilan Login}

Gambar 4 merupakan tampilan halaman login yang digunakan oleh admin untuk memasukkan data-data mahasiswa baru.

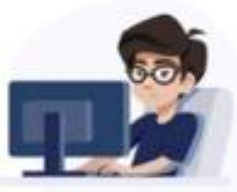

\section{Login Administrator}

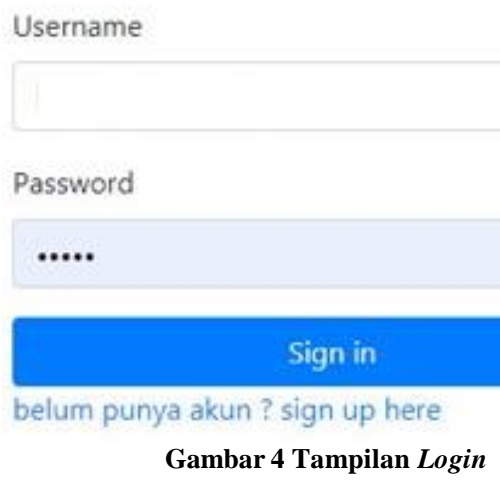

\subsection{Tampilan Home Admin}

Pada halaman home admin tampil data mahasiswa baru secara lengkap, selain itu admin juga bisa menambah, mengubah dan menghapus data mahasiswa baru. Tampilan home admin dapat dilihat pada Gambar 5. 


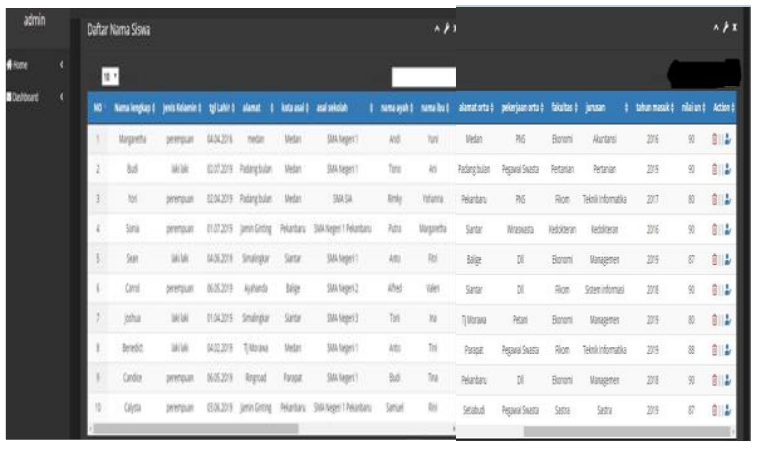

Gambar 5 Tampilan Home Admin

\subsection{Tampilan Daftar Mahasiswa Baru}

Gambar 6 merupakan tampilan daftar mahasiswa baru, dimana hanya admin yang bisa memasukkan data mahasiswa baru.

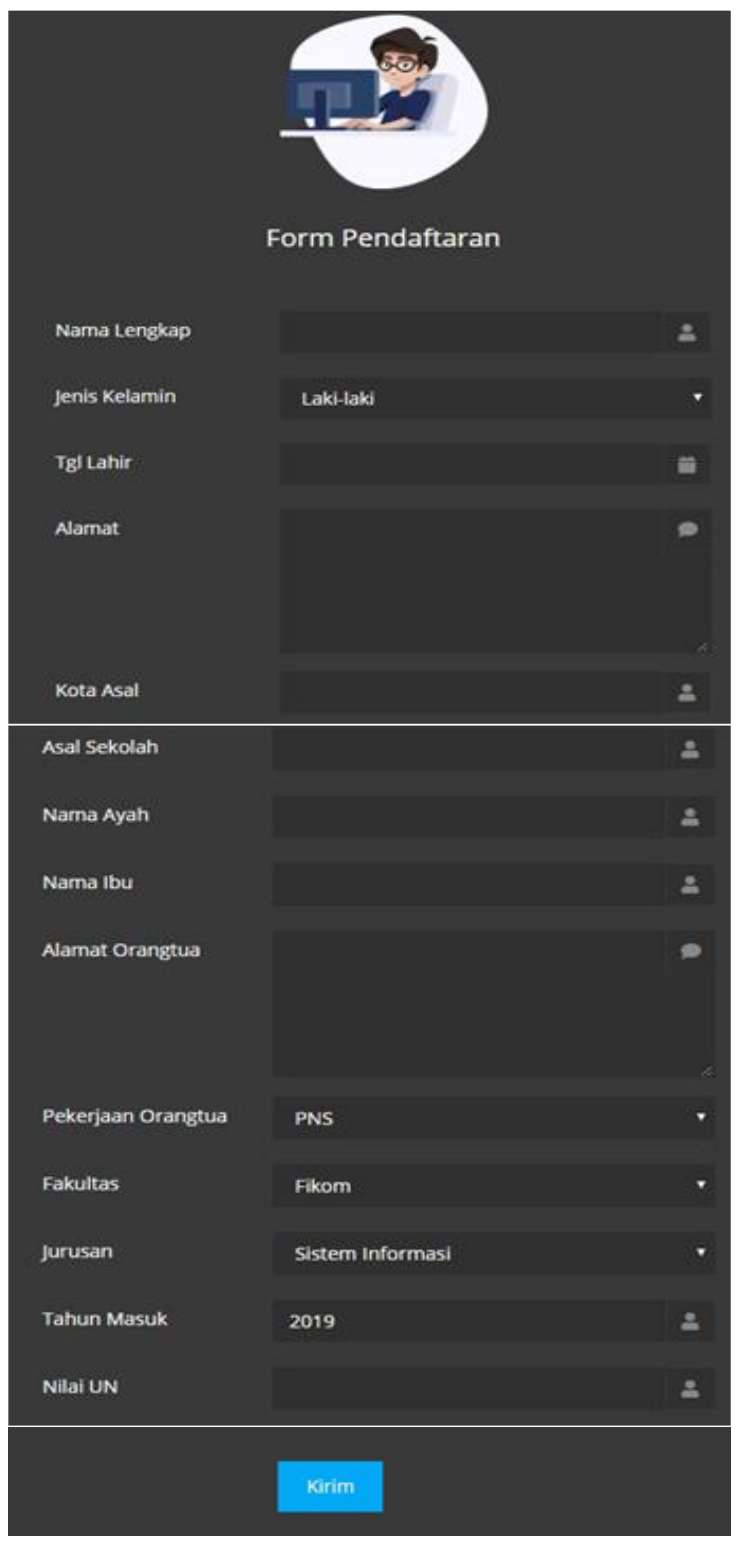

Gambar 7 Tampilan Daftar Mahasiswa Baru

\subsection{Tampilan Dashboard Berdasarkan Tahun} Masuk Kuliah

Gambar 8 merupakan dashboard mahasiswa baru berdasarkan tahun masuk kuliah dari mahasiswa baru. Tampilan dashboard baik sebagai admin maupun pengguna lainnya sama.

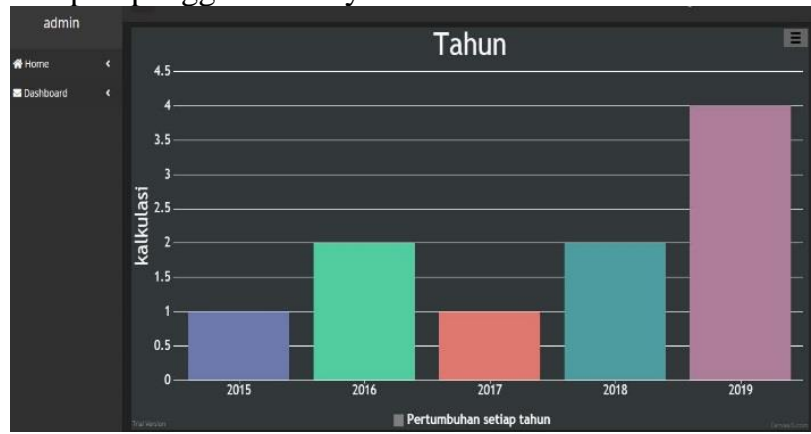

Gambar 8 Tampilan Dashboard Berdasarkan Tahun Masuk Kuliah

\subsection{Tampilan Dashboard Berdasarkan Fakultas}

Gambar 9 merupakan dashboard mahasiswa baru berdasarkan fakultas yang diambil oleh mahasiswa baru dari tahun 2015-2019. Tampilan dashboard baik sebagai admin maupun pengguna lainnya sama.

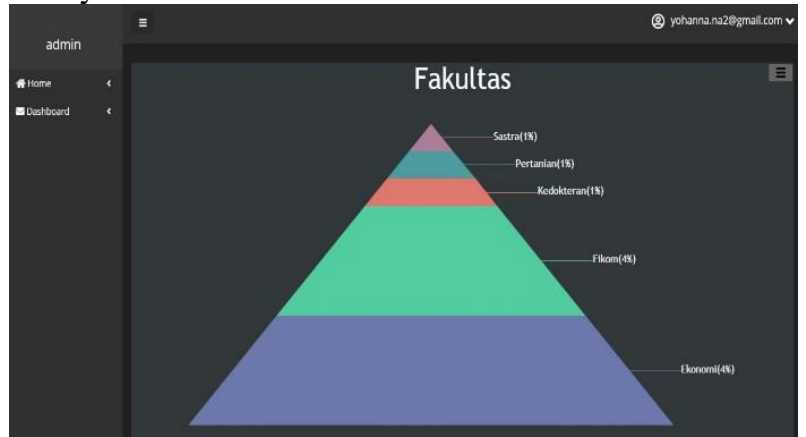

Gambar 9 Tampilan Dashboard Berdasarkan Fakultas

3.6. Tampilan Dashboard Berdasarkan Kota Asal Gambar 10 merupakan dashboard mahasiswa baru berdasarkan kota asal dari mahasiswa baru dari tahun 2015-2019. Tampilan dashboard baik sebagai admin maupun pengguna lainnya sama.

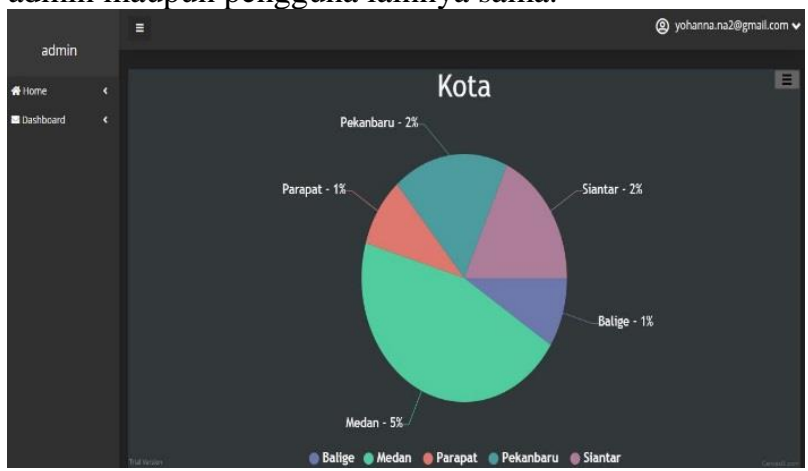

Gambar 10 Tampilan Dashboard Berdasarkan Kota Asal

\subsection{KPI 1: Kinerja Pengukuran KPI Berdasarkan} Tahun Masuk Kuliah.

Tabel 1 merupakan kinerja pengukuran KPI berdasarkan Tahun Masuk Kuliah. Kolom "target" 
merupakan target mahasiswa baru berdasarkan tahun masuk kuliah dari tahun 2015-2019. Kolom "realisasi" merupakan data jumlah mahasiswa baru. Kolom "rasio" merupakan persentasi realisasi mahasiswa baru yang mendaftar dibagi dengan target yang ditetapkan oleh pihak Rektorat. Dari tahun 2015-2019 jumlah target mahasiswa baru berdasarkan tahun masuk kuliah yaitu tahun 2015 sebesar 800 orang, tahun 2016 sebesar 870 orang, tahun 2017 sebesar 970, tahun 2018 sebesar 1.050 dan tahun 2019 sebesar 1.200 orang dengan total keseluruhan mahasiswa baru yang ditargetkan sebesar 4.890 orang.

Pada tahun 2015 jumlah mahasiswa baru yang mendaftar sebesar 670 orang dengan rasio $84 \%$. Pada tahun 2016 jumlah mahasiswa baru yang mendaftar sebesar 754 orang dengan rasio $87 \%$. Pada tahun 2017 jumlah mahasiswa baru yang mendaftar sebesar 712 orang dengan rasio $73 \%$. Pada tahun 2018 jumlah mahasiswa baru yang mendaftar sebesar 854 orang dengan rasio $81 \%$. Pada tahun 2019 jumlah mahasiswa baru yang mendaftar sebesar 1.055 orang dengan rasio $88 \%$. Dari keseluruhan target yang ditetapkan oleh pihak Rektorat berdasarkan tahun masuk kuliah dan realisasi jumlah mahasiswa baru yang mendaftar didapatkanlah rasio jumlah mahasiswa baru dari tahun 2015-2019 sebesar 83\%.

Tabel 1 Kinerja Pengukuran KPI Berdasarkan Tahun

\begin{tabular}{c|ccc}
\multicolumn{4}{|c}{ Masuk Kuliah } \\
\hline Tahun & Target & Realisasi & Rasio \\
\hline 2015 & 800 & 670 & $84 \%$ \\
2016 & 870 & 754 & $87 \%$ \\
2017 & 970 & 712 & $73 \%$ \\
2018 & 1050 & 854 & $81 \%$ \\
2019 & 1200 & 1055 & $88 \%$ \\
Total & $\mathbf{4 8 9 0}$ & $\mathbf{4 0 4 5}$ & $\mathbf{8 3 \%}$ \\
\hline
\end{tabular}

\subsection{KPI 2: Kinerja Pengukuran KPI Berdasarkan Fakultas.}

Tabel 2 merupakan kinerja pengukuran KPI berdasarkan Fakultas. Kolom "target" merupakan target mahasiswa baru berdasarkan fakultas dari tahun 2015-2019. Kolom "realisasi" merupakan data jumlah mahasiswa baru. Kolom "rasio" merupakan persentasi realisasi mahasiswa baru yang mendaftar dibagi dengan target yang ditetapkan oleh pihak Rektorat. Dari tahun 20152019 jumlah target mahasiswa baru berdasarkan fakultas yaitu Fikom sebesar 1.160 orang, Sastra sebesar 410 orang, Pertanian sebesar 800 orang, Ekonomi sebesar 2.160 dan Kedokteran sebesar 360 orang dengan total keseluruhan mahasiswa baru yang ditargetkan sebesar 4.890 orang.

Dari tahun 2015-2019 jumlah mahasiswa baru yang mendaftar berdasarkan fakultas yaitu Fikom sebesar 1.019 orang dengan rasio $88 \%$. Jumlah mahasiswa baru yang mendaftar di fakultas
Sastra sebesar 265 orang dengan rasio 65\%. Jumlah mahasiswa baru yang mendaftar di fakultas Pertanian sebesar 605 orang dengan rasio $76 \%$. Jumlah mahasiswa baru yang mendaftar di fakultas Ekonomi sebesar 1.894 dengan rasio $88 \%$ dan jumlah mahasiswa baru yang mendaftar di fakultas Kedokteran sebesar 262 orang dengan rasio $73 \%$. Dari keseluruhan target yang ditetapkan oleh pihak Rektorat berdasarkan Fakultas dan realisasi jumlah mahasiswa baru yang mendaftar didapatkanlah rasio jumlah mahasiswa baru dari tahun 2015-2019 sebesar $83 \%$.

Tabel 2 Kinerja Pengukuran KPI Berdasarkan

\begin{tabular}{c|ccc}
\hline \multicolumn{4}{|c}{ Fakultas } \\
\hline Fakultas & Target & Realisasi & Rasio \\
\hline Fikom & 1160 & 1019 & $88 \%$ \\
Sastra & 410 & 265 & $65 \%$ \\
Pertanian & 800 & 605 & $76 \%$ \\
Ekonomi & 2160 & 1894 & $88 \%$ \\
Kedokteran & 360 & 262 & $73 \%$ \\
Total & $\mathbf{4 8 9 0}$ & $\mathbf{4 0 4 5}$ & $\mathbf{8 3 \%}$ \\
\hline
\end{tabular}

\subsection{KPI 1: Kinerja Pengukuran KPI Berdasarkan} Kota Asal.

Tabel 3 merupakan kinerja pengukuran KPI berdasarkan Kota Asal. Kolom "target” merupakan target mahasiswa baru berdasarkan jurusan dari tahun 2015-2019. Kolom "realisasi" merupakan data jumlah mahasiswa baru. Kolom "rasio" merupakan persentasi realisasi mahasiswa baru yang mendaftar dibagi dengan target yang ditetapkan oleh pihak Rektorat. Dari tahun 20152019 jumlah target mahasiswa baru berdasarkan kota asal yaitu Medan sebesar 1.160 orang, Parapat sebesar 940 orang, Siantar sebesar 970 orang, Balige sebesar 940 orang, dan Pekanbaru sebesar 880 orang dengan total keseluruhan mahasiswa baru yang ditargetkan sebesar 4.890 orang.

Dari tahun 2015-2019 jumlah mahasiswa baru yang mendaftar dari kota Medan sebesar 1.085 orang dengan rasio 94\%. Jumlah mahasiswa baru yang mendaftar dari kota Parapat sebesar 662 dengan rasio $89 \%$. Jumlah mahasiswa baru yang mendaftar dari kota Siantar sebesar 850 orang dengan rasio $88 \%$. Jumlah mahasiswa baru yang mendaftar dari kota Balige sebesar 678 orang dengan rasio $72 \%$. Jumlah mahasiswa baru yang mendaftar dari kota Pekanbaru sebesar 770 orang dengan rasio $88 \%$. Dari keseluruhan target yang ditetapkan oleh pihak Rektorat berdasarkan Kota Asal dan realisasi jumlah mahasiswa baru yang mendaftar didapatkanlah rasio jumlah mahasiswa baru dari tahun 2015-2019 sebesar 83\%. 
Tabel 3 Kinerja Pengukuran KPI Berdasarkan Kota Asal

\begin{tabular}{c|ccc}
\hline Kota Asal & Target & Realisasi & Rasio \\
\hline Medan & 1160 & 1085 & $94 \%$ \\
Parapat & 940 & 662 & $70 \%$ \\
Siantar & 970 & 850 & $88 \%$ \\
Balige & 940 & 678 & $72 \%$ \\
Pekanbaru & 880 & 770 & $88 \%$ \\
Total & $\mathbf{4 8 9 0}$ & $\mathbf{4 0 4 5}$ & $\mathbf{8 3 \%}$ \\
\hline
\end{tabular}

\section{KESIMPULAN}

Adapun kesimpulan yang dibuat peneliti yaitu aplikasi dashboard monitoring penerimaan mahasiswa baru ini dapat membantu pihak rektorat, dekanat maupun pihak lain yang terlibat dalam penerimaan mahasiswa baru dalam memantau jumlah mahasiswa baru sehingga bila terjadi penurunan jumlah mahasiswa dapat dengan cepat diketahui dan diambil langkah apa yang harus dilakukan dalam mengatasi masalah tersebut.

\section{UCAPAN TERIMA KASIH}

Peneliti mengucapkan terima kasih kepada Direktorat Riset dan Pengabdian Masyarakat, Kementerian Riset, Teknologi, dan Pendidikan Tinggi yang telah mendanai penelitian ini sehingga penelitian ini berjalan dengan baik dan lancar.

\section{DAFTAR PUSTAKA}

Y. Muhamad, F.Ade, H. Uswatun, and A. Siti. 2012. Dashboard Information System Evaluasi Sistem Penerimaan Mahasiswa (Sinema) pada Perguruan Tinggi Raharja. Konferensi Nasional ICT-M Politeknik Telkom (KNIP), ISSN 2302-1896, pp. 276-280.

N.B. I Gst Ngurah, W.I Gst Ngurah. 2017. Visualisasi Dashboard Penerimaan Mahasiswa Baru di STIKOM Bali. Konferensi Nasional Sistem dan Informatika, pp. 401-406.

Parmenter, D. 2007. Key Performance Indicator: Developing, Implementating, and Using Winnning KPI, John Wiley and Sons Inc, New Jersey.

A. Haryono. 2012. Pengembangan Sistem Informasi Pengolahan Data Pegawai Sekolah Menengah Pertama Negeri (SMPN) 4 Pacitan. J. Speed - Sentra Penelitian Engineering dan Edukasi, vol. 4, no. 3, pp. $1-9$.

D. Ridho. 2018. Pembangunan Dashboard Lokasi Rawan Tanah Longsor di Indonesia Menggunakan Tableau.2018. Jurnal Teknik Informatika dan Sistem Informasi, vol 4, no 2, ISSN 2443-2229, pp. 254-267.

M. Ropianto. 2017. Pemanfaatan Sistem Dashboard Pada Data Akademik Di
Sekolah Tinggi Teknik (STT) Ibnu Sina Batam. Jurnal Teknik Ibnu Sina JT-IBSI, vol 2, no 2, pp. 67-71.

A. D. Aipassa, I. Darmawan, and R. Andreswari. 2017. Pembuatan Dashboard Pada Sistem Informasi Pengadaan Barang dan Jasa dengan Metode Extreme Programming (Studi Kasus Logistik Universitas Telkom). Eproceedings of Engineering, paper 4.1, pp. 1005-1011.

D. Nurmalasari, R. T. Wahyuni, and Y. Palapa. 2015. Informational Dashboard untuk Monitoring Sistem Drainase secara RealTime. JNTETI (Junal Nasional Teknik Elektro dan Teknologi Informasi), vol. 4, no. 3.

T. Imam. 2016. Perancangan Data Warehouse Untuk Mndukung Kebutuhan Informasi Penjualan dalam Pengambilan Keputusan (Studi kasus: Sesko Mart). Tugas Akhir Universitas Widyatama.

M. Ropianto. 2017. Pemanfaatan Sistem Dashboard Pada Data Akademik Di Sekolah Tinggi Teknik (STT) Ibnu Sina Batam. Jurnal Teknik Ibnu Sina JT-IBSI, vol. 2, no. 2, pp. 67-71. 